\title{
El coco, signo de la cultura creole de Corn Island'
}

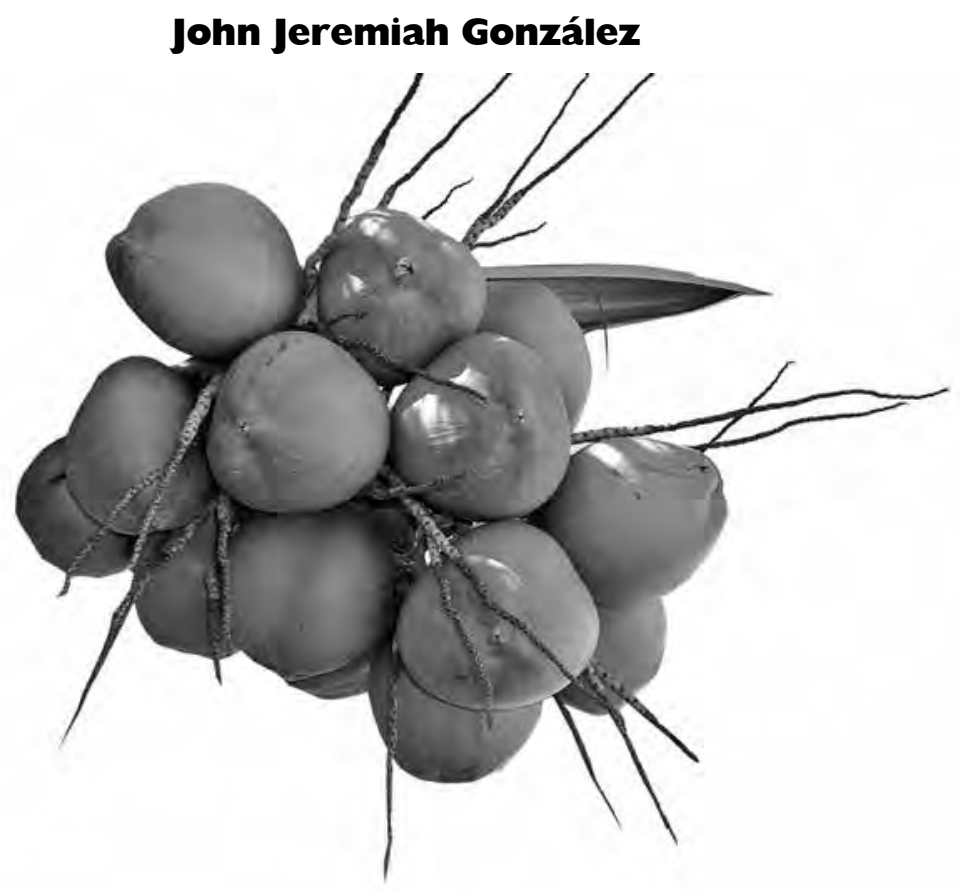

El coco es el ingrediente que da personalidad a la mayor parte de la dieta gastronómica caribeña del pueblo creole de Corn Island. Esta fruta, además de dar de comer y beber en un mismo plato, también ofrece el punto de sabor indispensable para la preparación de platillos y alimentos cotidianos. De la leche de coco se extrae el aceite que le da gusto y aroma al desayuno, al rice and beans, a las carnes, el rundown, la sopa de cangrejos y otros mariscos, incluidos los postres y golosinas, panes, dulces y atoles. Lo que queda del coco se utiliza para alimentación de los animales domésticos como el cerdo, la gallina, la vaca y el caballo. La estopa y la concha de coco son utilizadas como combustión para cocinar y hornear los diversos platillos. Y también se emplea grandemente como material para la elaboración de diversos tipos de artesanías. La estopa se usa también como un cepillo para ejecutar la limpieza de la casa. Y según cuentan los portadores culturales, desde tiempos ancestrales, los creoles de Corn Island, como muestras de atención a sus visitantes, los reciben con un coco tierno para calmar la sed, refrescar el cuerpo y favorecer la función renal, entre otras de sus virtudes medicinales.

1 Este es un fragmento tomado de la investigación “Gastronomía de los Creoles de Corn Island” Región Autónoma del Atlántico Sur (R.A.A.S.), la cual fue financiada por el Fondo de investigaciones para la revitalización cultural y desarrollo productivo creativo de la Costa Caribe de Nicaragua. 